\title{
Performance e documentário de memória afetiva
}

Cássio dos Santos Tomaim

Universidade Federal de Santa Maria - UFSM, Santa Maria, Rio Grande do Sul, Brasil

\section{Resumo}

Este artigo propõe uma aproximação entre performance e memória traumática e suas implicações para a narrativa documentária em primeira pessoa (autobiográfica). A performance é entendida como um comportamento expressivo capaz de transmitir a memória e a identidade cultural, a partir da valorização tanto do repertório quanto do arquivo, como proposto por Diana Taylor (2013). Nesse tipo de cinema, o testemunho é da ordem da performance, de uma performance afetiva do documentarista. O teor testemunhal desses documentários se reveste de um potencial afeccional, em que o cineasta que narra é também afetado pela narração do trauma/passado.

\section{Palavras-chave}

Documentário autobiográfico.

Performance. Memória traumática.

\section{Introdução}

Desde meados de 1980 acompanhamos uma mercantilização da memória, o passado ou a lembrança do passado, nas suas mais diversas formas, tornou-se um produto atraente nas prateleiras de livrarias, supermercados, nas vitrines dos shoppings, na televisão e no cinema. O passado histórico nunca esteve tão acessível ou próximo de nós como nos dias de hoje, porém, esta enxurrada de informações armazenadas e transmitidas pelos diversos suportes midiáticos ameaça a memória, assim como nosso conhecimento histórico, uma vez que "a referência ao passado não se dá de forma única, em momento algum; mais que isso, chega-se a uma estrutura sempre mais complexa de superposições e entrecruzamentos entre diferentes planos da memória: o plano dos textos, dos objetos remanescentes, dos vestígios e do lixo" (ASSMANN, 2011, p. 233).

Diante desta sedução pelo tema da memória, Andreas Huyssen (2000, p. 20-21) faz o alerta: “[...] não podemos discutir memória pessoal, geracional ou pública sem 
considerar a enorme influência das novas tecnologias de mídia como veículos para todas as formas de memória”. Neste termo, o documentário, como "mídia de memória" (ASSMANN, 2011), não escapa a este contexto político e cultural que alguns autores (HARTOG, 2014; WINTER, 2006) denominaram de "boom da memória".

Ainda neste contexto, no que diz respeito à história do documentário, vemos o surgimento de um tipo de "cinema do Eu" que evoca um novo lugar para o documentarista. Se na origem do documentário temos um sujeito compromissado ética e esteticamente com a representação do Outro, na década de 1980 uma modalidade de documentário coloca em primeiro plano a figura do cineasta. Sem muito pudor o Outro da alteridade é deslocado ou até mesmo apagado do seu lugar de objeto representacional. Esta modalidade de documentário Bill Nichols (2005) definiu como "documentário performático", cinema em que o ponto de partida é um problema individual, íntimo do cineasta. Nesse tipo de documentário, o relato em primeira pessoa coloca o cineasta no centro da narrativa documentária, reclamando para este tipo de cinema sua dimensão subjetiva. Entretanto, nem todo documentário em primeira pessoa parte de questões psicológicas, afetivas e íntimas do seu realizador, logo, nem todo documentário que se vale deste tipo de narrativa (em primeira pessoa) pode ser considerado performático, uma vez que não está em jogo um entendimento e uma representação de si mesmo (a do realizador).

O presente artigo procura contribuir com o debate a respeito das implicações da narração em primeira pessoa nos documentários autobiográficos, problematizando a relação entre performance e memória traumática. Não se tem a pretensão de apresentar uma proposta de método analítico, tão pouco de pensar categorias fechadas para abordar este tipo de cinema documentário que prioriza uma "escrita do eu" ou uma "escrita de si", portanto, os filmes que figuram neste artigo são apenas pontos de partida para as reflexões teóricas que proponho ao colocar em diálogo memória, cinema e performance.

Também se reconhece a necessidade de subcategorizar o cinema que aqui está em análise, por entender que nem todo documentário narrado em primeira pessoa, ou até mesmo que nem todo documentário autobiográfico tem implicado na sua origem uma performance afetiva do cineasta, que nos leva a pensar no "documentário de memória afetiva" como um subproduto do "documentário de memória" (GAUTHIER, 2011). 
O olhar para as performances no documentário é menos para as teatralizações que colocam em cena o documentarista e sim para uma atitude performática que não necessariamente pressupõe um estar em cena; é este estar em cena, mas também é um estado que manifesta um comportamento (ou um gesto) expressivo capaz de transmitir ${ }^{1}$ uma memória e identidade cultural. Trata-se de pensar como a performatização de uma memória - que encontra materialidade (sua dimensão arquivística) em forma de filme - coloca em jogo "os roteiros que compõem os imaginários individuais e coletivos" (TAYLOR, 2013, p.378).

\section{Entre 0 arquivo e 0 repertório}

Segundo Taylor, a História baniu o repertório para o passado em detrimento do arquivo, apoiando-se em alguns mitos. A memória "arquivística" existe na dependência de suportes que sejam capazes de um armazenamento duradouro. $\mathrm{O}$ arquivo excede o que acontece ao vivo. Porém, para a autora, acreditar no arquivo como algo não mediado, que não seja vulnerável a alterações ou manipulações que favorecem certos projetos políticos de memória, é um dos primeiros mitos que precisam ser abandonados para que possamos voltar a olhar para o repertório como aquele que encena a memória incorporada. Nas palavras da autora: "o repertório, seja em termos de expressão verbal ou não verbal, transmite ações incorporadas reais. Assim, as tradições são armazenadas no corpo, por meio de vários métodos menmônicos, e são transmitidas 'ao vivo' no aqui e agora, para uma audiência real" (2013, p. 55).

Mais do que dicotomizar entre o arquivo e o repertório, a autora propõe que ambos têm sido fontes importantes de conhecimento, variando o grau de importância de um e outro conforme o tipo de sociedade (letrada/semiletrada). Para Taylor (2013, p. 70-71), "o ato de contar é tão importante quanto o de escrever; o fazer é tão central quanto o registrar a memória passada por meio dos corpos e de práticas mnemônicas"; ambos os sistemas arquivo e repertório - se complementam, um não contraria a lógica do outro.

1 A autora emprega o termo "transmissão" no sentido de que a memória experiencial pode ser compartilhada, que 0 conhecimento de uma experiência passada, vivida, encontra na performance, assim como no arquivo, uma forma de transpor as gerações. Conhecimento que se manifesta como traço de uma herança cultural. No caso da transmissão da experiência traumática, Taylor concebe que ela se assemelha a um "contágio", aquele que ouve ou acompanha uma recordação - que deve ser interpretado aqui como o ato performático da memória - incorpora o peso, a dor e a responsabilidade associada ao evento traumático. Mas isto não quer dizer que aquele que testemunhou deixa de sofrer, que se verá livre do trauma. 0 contágio é um compartilhamento virtual da experiência traumática. 
Enquanto a performance atualiza o repertório no tempo agora, no "ao vivo", o arquivo cristaliza fragmentos do repertório. Então, temos que a vida da performance se limita ao presente. Não pode ser salvada, gravada, documentada:

A performance "ao vivo" nunca pode ser captada ou transmitida por meio do arquivo. Um vídeo de uma performance não é uma performance, embora frequentemente acabe por substituir a performance como uma coisa em si (o vídeo é parte do arquivo; o que representa é parte do repertório). A memória incorporada está 'ao vivo', excede a capacidade do arquivo de captá-la. Porém, isso não significa que a performance como comportamento ritualizado, formalizado ou reiterativo - desaparece. As performances também replicam a si mesmas por meio de suas próprias estruturas e códigos (TAYLOR, 2013, p.51).

Segundo Taylor, não se propõe aqui simplesmente mudar o foco para o "ao vivo" como objeto de análise, o que talvez dependeria de adotar outras estratégias para a coleta de dados, como a pesquisa etnográfica, entrevistas e anotações de campo. Ao contrário disto, a autora nos provoca a repensar o nosso método de análise, "ao invés de privilegiar textos e narrativas, poderíamos também ver os roteiros como paradigmas para a construção de sentidos que estruturam os ambientes sociais, comportamentos e conseqüências potenciais" (TAYLOR,
2013, p. 60). Roteiros estes que estão manifestados nas performances afetivas dos documentaristas que enfrentam o desafio de atualizar suas memórias traumáticas, mesmo que o filme nos ofereça apenas fragmentos destas performances, já que se trata de um registro que satisfaz mais o sistema arquivístico.

No entanto, o filme não exclui o repertório como parte de uma ação de intervir e interpretar o mundo vivido que se dá na própria feitura deste filme. Cabe ao analista encontrar novas ferramentas metodológicas ou aprimorar as já existentes, pois não se trata de abandonar o lugar privilegiado dos textos e das narrativas na análise fílmica, mas complementar a análise acrescentando a ela dispositivos capazes de identificar os rastros destas memórias incorporadas. Quando pensamos em um conjunto de documentários que abordaram as memórias traumáticas das ditaduras na América Latina, por exemplo, podemos nos perguntar: o que estes filmes têm a nos dizer sobre os roteiros dos traumas da repressão, do exílio, do desaparecimento, na perspectiva de que "[...] os roteiros moldam e ativam os dramas sociais" (TAYLOR, 2013, p. 61)? Um estudo mais denso de como esta memória é performatizada por meio 
de uma narrativa autobiográfica ainda está por ser feito, por enquanto restam as problematizações. $^{2}$

Ao comentar sobre a insistência no "ao vivo" da performance, a autora diz não ter a intenção de diminuir a importância dos testemunhos virtuais e em vídeo colocados em circulação nas últimas décadas, tão pouco acreditar que a transmissão da memória traumática aconteça apenas no encontro "ao vivo", pelo contrário,

[...] elas [estas iniciativas de sistema arquivístico, como o filme documentário] armazenam conhecimento e o disponibilizam para um número maior de pessoas do que qualquer roteiro 'ao vivo'. Mas o 're' de 'recaptar' não é a repetição reiterativa do trauma ou da performance, mas uma transferência para 0 arquivo - uma economia de armazenamento e representação diferente (TAYLOR, 2013, p. 402).

Por mais que diante de um filme não podemos mais falar em performance, pois segundo a autora, "a memória incorporada está 'ao vivo' e excede a capacidade do arquivo de captá-la"
(TAYLOR, 2013, p. 51), arrisco a dizer que em "documentários de memória afetiva" os vestígios do repertório estão mais presentes do que em outros tipos de documentários, pois neles há uma forte carga emotiva que está na origem da atitude documentária do realizador. Por ser produto de um dever de memória, de um engajamento do cineasta com o passado, este tipo de cinema que venho denominando de "documentário de memória afetiva" lhe cobra outra postura narrativa. Este documentarista não é um narrador qualquer, é um narrador implicado na cena, em que recordar é assumido por ele como um ato político. Recordação esta que também é uma performance.

Assim como Sarmento-Pantoja (2016), vejo a necessidade de ampliarmos a leitura do conceito de performance, uma vez que limitar o potencial performático à condição da sua execução "ao vivo" nega outros tantos aspectos que envolvem a sua própria fixação ou registro em um suporte midiático. Segundo o autor, a ação performática não

2 A tese Performance, Trauma e Testemunho no Cinema Pós-64 (2016), de Carlos Augusto Nascimento SarmentoPantoja já nos oferece algumas respostas ao analisar os documentários Que bom te ver viva (Lúcia Murat, 1989) e No olho do furacão(Renato Tapajós e Toni Venturi, 2002). 0 autor atrela o conceito de performance ao de testemunho, logo, "A performance neste caso expressa a necessidade de recuperar as memórias as quais aterrorizam o testemunhador" (2016, p.198). 0 documentarista é este sujeito performador/testemunhador, em que suas ações performáticas procuram testemunhar o horror do trauma, expressarem "[...] em suas narrativas 'segredos' revelados de um passado difícil e passivo de ser superado, mas as câmeras e todo aparato técnico requerem uma filmagem a qual pressupõe uma observação de si, fazendo com que a narração seja anteriormente pensada para que diante da câmera e do diretor seja dado seu depoimento" (SARMENTO-PANTOJA, 2016, p.197). 
é realizada apenas pelo artista, o performador, mas também por outro personagem: o performante. Aquele que é ao mesmo tempo destinatário e responsável para que o enunciado performático seja validado. No caso do documentário quem ocupa este lugar é o espectador, por mais que seja ele sujeito de uma ação performática mediada.

Assim 0 ato performático não se concretiza somente na arte do aqui e agora. Ela pode ser compreendida também após sua fixação, já que há um princípio performático em toda forma de linguagem, que leva o performante a performar no momento de sua experiência com objeto artístico (SARMENTO-PANTOJA, 2016, p.173).

O "documentário de memória afetiva" exige do cineasta uma performance afetiva que é ao mesmo tempo um estar no mundo e interpretá-lo. O sujeito que narra é também uma testemunha a quem não se dispensa um potencial afeccional. É um sujeito afetado pelo passado/trauma, o ato de recordar instaura uma temporalidade em que a hegemonia do presente sobre o passado no discurso fílmico é da ordem da experiência, em muitos casos, da ordem da experiência traumática.

Segundo Comolli (2008), opera-se no documentário autobiográfico um complexo jogo de presença/ausência, de mostrar-se/esconder-se em que este corpo do cineasta que é colocado em cena acrescenta uma nova dimensão ao documentário: a filmagem torna-se uma experiência do corpo afetado. O filme é produto desta afetação. Ainda conforme o autor,

'corpo', aqui, vale como manifestação sensível de uma subjetividade, de uma história do sujeito que precisamente sua fala [...] dobra e desdobra no tempo real da tomada. Nessa duração, há algo de uma libido que se esgota: desejo de ser filmado, desejo de filmar, de falar, de jogar o jogo do plano-sequência (p. 286).

Para colocar em exemplo esta potência afeccional do documentário recorremos ao filme Cuchillo de Palo (2010), de Renate Costa. Nesse filme, a diretora paraguaia investiga o mistério em torno da morte do seu tio, Rodolfo Costa, que foi perseguido pela ditadura de Alfredo Stroessner no Paraguai, na década de 1980, por conta de sua orientação sexual. Durante as filmagens a cineasta descobre que o tio fazia parte da "lista dos 108", um grupo de homossexuais que foi perseguido pelo regime da época. Fato que o pai da cineasta, irmão de Rodolfo Costa, prefere negar. Depois de uma pescaria frustrada entre pai e filha, ambos se sentam diante de uma mesa na qual começam uma conversa sobre o que ocorreu com Rodolfo Costa. É a penúltima sequência do documentário. Diante de documentos oficiais do regime, o pai de Renate Costa insiste no que dizem os arquivos, que o seu irmão foi apenas detido. Nega que a morte dele esteja 
relacionada com a tortura sofrida nos porões da ditadura, como acredita a documentarista. Pai e filha entram em conflito e acompanhamos tudo pela câmera de Cuchillo de Palo, que registra seus corpos em um duradouro plano sequência. Por mais que não seja Renate Costa que opera a câmera, a decisão final por manter a cena no filme é dela, na fase de pós-produção (montagem), o que revela uma sensibilidade para esta dimensão da afetação que marca o "documentário de memória afetiva". Durante a cena, após o auge da discussão entre pai e filha, presenciamos o silêncio reinar na tela e abrir-se para um vácuo temporal entre os dois personagens. O silêncio dura, a câmera procura pelos rostos, pelas reações (ou não reações) de pai e filha. Ambos são afetados por sentimentos, ressentimentos que escapam à compreensão do espectador do filme, mas "a performance filmada atesta a validade da experiência cinematográfica" (COMOLLI, 2008, p.290). O silêncio no filme é tanto a metáfora do próprio processo de silenciamento a qual ainda estão submetidos os eventos traumáticos da ditadura na sociedade paraguaia, quanto produto da síntese que envolve conflitos de geração em torno da temática de gênero. Ao final do plano sequência, a documentarista abandona o silêncio para dizer ao pai o que sente: "é difícil nos entendermos"; e sai da mesa, sai do quadro, enquanto que a câmera se volta para o pai, que permanece inerte.

\section{Documentário de memória afetiva}

Foi Guy Gauthier (2011) quem propôs uma distinção entre "documentário no presente" e "documentário de memória". No primeiro, segundo o autor, o cineasta tenta apreender o vivido, aproximar-se da "vida como ela é", o filme tem forte apelo ao presente. Já o segundo é o que o senso comum denomina de "documentário histórico", podendo ser também indexado como "documentário de arquivo", "filme testemunho" etc. No "documentário de memória" o cineasta tem interesse por compreender o passado, o seu gesto visa uma atualização da memória seja por meio de testemunhos, arquivos e vestígios. No entanto, não se pode negar que o trabalho do documentarista se dá no presente, quando se interessa pelo passado o explora com os indícios no presente (GAUTHIER, 2011). Logo, o "documentário de memória" também exige uma ética da escritura fílmica.

Escritura que revela o documentário como uma arte vocacionada (em termos políticos) para a memória, uma dimensão ética do presente em que rememorar para uma câmera reveste o ato de um sentido de resistência que, por sua vez, carrega em si a potência da experiência do vivido, da crítica e da revelação. O documentarista é aquele que deseja salvar uma imagem do passado, está "[...] submetido ao que, um dia foi. Tem uma dívida para com o passado, uma dívida de 
reconhecimento para com os mortos, que faz dele um devedor insolvente" (RICOEUR, 2010b, p. 237). Aqui este "dever de memória" induz uma relação afetiva e moral com o passado, mas que apresenta estratos diferentes. Nem todo cineasta que se propõe a fazer um "documentário de memória" reconhece esta dívida com o passado, em alguns casos o passado é apenas um objeto a ser representado, mas isto não faz o filme deixar de ser classificado como "documentário de memória", nos termos de Gauthier (2011). Por isto, diante de documentários que nitidamente se revestem deste "dever de memória", vejo a necessidade de pensarmos neles como subprodutos do "documentário de memória". Filmes que o documentarista demonstra uma relação mais visceral com o passado, assumida geralmente por uma narrativa em primeira pessoa, sendo este um narrador também implicado no processo de recordação que o filme opera, sugiro denominarmos de "documentário de memória afetiva".

O que nos interessa é pensar filmes documentários que apresentam no seu "DNA" estético e ético um potencial de afetação que conduz a narrativa à atualização de uma memória que é individual (autobiográfica), a priori, mas que pela performance do cineasta no processo de fazer o filme, que implica também em um processo de recordação, se apresenta esta como uma memória coletiva, ou pelo menos como uma memória que se pretende coletivizar em termos de sua dimensão afetiva que traz em cena um dever de justiça, um dever de memória.

Deste narrador implicado não se espera apenas um compromisso moral com o passado que visa reconstruir, o seu compromisso deriva de uma afetação, é ele um sujeito afetado pelo passado que representa. O emprego do termo afetivo na composição de um tipo de memória, a memória afetiva, pode nos remeter indiscriminadamente à ideia de afeto ou paixão, ou de lembranças motivadas por fortes emoções. Entretanto, é preciso reconhecer a partir dos estudos da neurociência que "toda memória é adquirida em um certo estado emocional [...]", sendo que "[...] a importância emocional de cada memória faz com que outras, às vezes importantes, adquiridas pouco antes ou depois, sejam literalmente obliteradas" (IZQUIERDO, 2010, p. 41-42). A memória afetiva pressupõe uma dimensão de afecção (ou afeição) em que "designa todo estado, condição ou qualidade que consiste em sofrer uma ação ou em ser influenciado ou modificado por ela" (ABBAGNANO, 2007, p. 19). Em alguns casos a ação é derivada de uma situação traumática, o que torna a sua recordação um peso, mas no tocante ao "documentário de memória afetiva" o cineasta escolhe não mais reprimir as memórias que lhe são desagradáveis ou insuportáveis, pelo 
contrário, o filme é produto deste enfrentamento com o passado, um combate ao esquecimento e a negação.

A memória afetiva da qual trato aqui tem relação com o que Marcel Proust denominou de memória involuntária: impressões realmente significativas do homem, que trancafiadas no reservatório do inconsciente só emergem pelo acaso. Já a memória voluntária é aquela lembrança que temos acesso por meio da ação do intelecto, "gavetas" de nossa memória que podemos abrir quando desejamos. Em outros termos, o que recordamos voluntariamente são apenas lembranças casuais de uma vida, pois somente a memória involuntária é capaz de nos dar acesso às dimensões essenciais do passado. Esta visão proustiana da memória sugere um passado que "brilha", que irrompe no presente como uma forma de atualização. Em diálogo com Proust, Walter Benjamin considera a memória involuntária a única capaz de mergulhar suas raízes na experiência. Temos, para o filósofo, a consciência como a resposta do homem moderno às ameaças dos choques, logo, se projeta para a modernidade o declínio da experiência. Quanto maior for a participação do fator choque nas impressões cotidianas do indivíduo, mais constante será a presença do consciente no intuito de proteger o homem contra os estímulos externos. O que equivale dizer que, quanto maior for o êxito do consciente nesta operação, menor são as chances dessas impressões serem incorporadas à experiência. Segundo Benjamin (1989, p. 108), "só pode se tornar componente da mémoire involontaire aquilo que não foi expressa e conscientemente 'vivenciado', aquilo que não sucedeu ao sujeito como 'vivência'."

Para o filósofo frankfurtiano, ao declínio da experiência se associa o fim da narração. Foi o narrador a figura que sintetizou uma época em que a matéria da narração e sua existência era a própria experiência, narrar era uma performance do vivido que, como aprendemos com Taylor (2013), também é capaz de transmitir e preservar a memória cultural. Nas palavras de Gagnebin (1994), o desaparecimento da antítese tempo-eternidade na percepção cotidiana da modernidade, tendo sido substituída pela perseguição incessante do novo, levou a uma redução drástica da experiência do tempo, segundo o pensamento benjaminiano, em que "[...] a construção de um novo tipo de narratividade passa, necessariamente, pelo estabelecimento de uma outra relação, tão social como individual, com a morte e com o morrer" (p. 74).

É nestes termos que interpreto este tipo de cinema documentário marcado por memórias afetivas. Tendo a apostar que o "documentário de memória afetiva" é parte deste novo tipo de narratividade em que os documentaristas 
encontram na linguagem do cinema maneiras de narrar o trauma ou a memória traumática, principalmente em uma perspectiva intimista, autorreferencial ou autobiográfica. Eles exercem papel inovador para o campo do documentário, não obstante, é preciso que se diga, não sem um aprendizado que se dá pela chave do trauma. O próprio sofrimento lhes ensina maneiras diferentes de lidar com a morte e com o morrer, e se espera que isto encontre matéria, forma no documentário.

Para tal empenho, é preciso olhar para os estabilizadores das recordações, como apresentados por Aleida Assmann (2011). Todo "documentário de memória" faz uso e tem uma dependência destes para se confirmar como uma narrativa de memórias traumáticas, como procurei demonstrar em trabalho anterior (TOM AIM, 2016). O primeiro deles é o afeto, que em narrativas autobiográficas é difícil não estar associado direta e indissolúvel ao processo de recordação. Porém, a autora faz uma ressalva: "que recordações em particular serão 'afetadas' por essa força estabilizadora, isso certamente foge ao controle do indivíduo, pois a participação afetiva em determinadas recordações justamente não pode ser controlada pelos indivíduos" (ASSMANN, 2011, p.270).

Neste caso, podemos dizer que o narrador implicado do "documentário de memória afetiva" não está preocupado com a precisão ou verificação, pode até deixar lacunas sobre os fatos históricos, mas não pode enganar o que sentiu. O que é focalizado nestes filmes é a relação que estes cineastas possuem com o passado representado, em que "não nos encontramos mais no campo da verdade, das histórias verdadeiras; entramos, sim, no campo da autenticidade. [...] A memória afetiva baseia-se em uma experiência psicofísica que escapa não apenas à verificação externa, como também à revisão própria" (ASSMANN, 2011, p. 271, grifo da autora). Para a autora, ter o afeto como estabilizador das recordações não é priorizar a verdade subjetiva em detrimento de um mundo experiencial objetivo e empiricamente assegurado. A incapacidade ou impossibilidade de assegurar uma verificação do que é recordado por aquele que testemunha o vivido apenas desloca a análise para uma preocupação mais atenta para a forma desta recordação. Já em termos estéticos, o que nos interessa é perceber como esta recordação autobiográfica atualiza o passado na narrativa documentária, tendo em vista que o cineasta, neste tipo de documentário, ocupa dois papéis simultaneamente: o de narrador (parte da operação ficcional da narrativa cinematográfica) e de testemunha (daquele que experimentou e fala do trauma ou do vivido no presente) aspectos que desenvolverei mais adiante. 
Segundo Assmann (2011, p. 283), o trauma instaura a impossibilidade da narração. Se por um lado encontra no corpo uma área de gravação, de "inscrição", por outro, é por ser uma inscrição profunda que o trauma priva o sujeito de uma experiência do processamento linguístico e interpretativo. $\mathrm{Na}$ contramão do trauma, surge o símbolo como estabilizador de recordações. "A recordação que ganha força de símbolo é compreendida pelo trabalho interpretativo retrospectivo em face da própria história de vida e situado no contexto de uma configuração de sentido particular" (ASSMANN, 2011, p. 275). Neste sentido, cabe pensarmos que sentimentos como humilhação, ambição, surpresa, estranhamento e mistificação também são ingredientes para o jogo da recordação. Estes (res)sentimentos podem mover certas interpretações do passado "[...] em que percepções se cristalizam como experiências, experiências como recordações" (ASSMANN, 2011, p. 275). Relacionando com o "documentário de memória afetiva", desprezar a leitura destas marcas de (res)sentimentos nas narrativas documentárias é o mesmo que subestimar a importância destas recordações reformuladas (ou reinterpretadas), uma vez que o filme é a própria busca por dar um sentido à experiência traumática do cineasta.

No entanto, é preciso que se diga, o afeto e o símbolo são estabilizadores de naturezas diferentes. Enquanto no primeiro os significados estão postos nas percepções e recordações em si mesmas, no segundo estes significados são reconstituídos a posteriori. Segundo a autora, "a estabilidade de uma parte essencial de nossas recordações depende da questão acerca da possibilidade de inventar e acrescentar um tal significado ou não", o que significa dizer que "[...] uma história de vida está baseada em recordações interpretadas que se fundem em uma forma rememorável e narrável" (ASSMANN, 2011, p. 276). No caso do documentário, a leitura pela via epistêmica da performance nos ajuda a compreender melhor os sentidos destas recordações interpretadas.

Por último, o trauma é entendido como um estabilizador de outra ordem, "[...] estabiliza uma experiência que não está acessível à consciência e se firma nas sombras dessa consciência como presença latente" (ASSMANN, 2011, p. 277), por isto a importância de se atentar para os silêncios, os pequenos gestos materializados na narrativa documentária que evoca testemunhos. Para a autora, o trauma apresenta uma contradição paradoxal, ele é presença e ausência. Apesar de pertencer ao homem como uma parte intransferível, o trauma não o constitui como sujeito, não é assimilado enquanto parte de sua identidade, é um corpo estranho. Nestes termos, Assmann (2011, p. 283, grifo da autora) nos 
chama a atenção para a seguinte triangulação entre os estabilizadores:

Se 0 afeto excede uma medida suportável e converte-se em um excesso, então não estabiliza mais as recordações, mas as destrói. É esse o caso do trauma, que transforma diretamente o corpo em uma área de gravação e, com isso, priva a experiência do processamento linguístico e interpretativo. 0 trauma é a impossibilidade da narração. Trauma e símbolo enfrentam-se em um regime de exclusividade mútua: impetuosidade física e senso construtivo parecem ser os pólos entre os quais nossas recordações se movimentam.

Por isto a importância de estudarmos os "documentários de memória afetiva". São eles um exercício de reelaboração do trauma por parte dos cineastas. Em muitos casos, o próprio ato de fazer o filme ajuda ao documentarista na operação de transpor as barreiras da memória traumática. Este tipo de cinema é um movimento do trauma para a ressignificação de um passado inscrito com dor, angústia e sofrimento. O "documentário de memória afetiva" é um sussurro por uma identidade já que sabemos que a memória tem algo a ver não apenas com o passado, mas também com a identidade e, por sua vez, com a própria persistência do sujeito no futuro.

Os cineastas que se arriscam a rememorar um passado traumático não sentem nostalgia deste tempo, mas os seus filmes parecem responder a uma "busca de narrativa", uma vez que toda experiência humana possui uma demanda por narrativa. Segundo Ricoeur, o ato de narrar apreende o mundo a partir das experiências humanas, experiências ou ações que são trazidas para o universo da linguagem, mas que já se encontram pré-significadas no mundo vivido. O autor compreende que uma ação só pode ser narrada porque ela já está articulada em signos, regras e normas, na sua origem ela já está "simbolicamente mediatizada” pelas convenções sociais e culturais. No entendimento de Ricoeur, toda experiência humana possui uma "estrutura pré-narrativa": "o enredamento [das ações] aparece, antes, como a 'pré-história' da história contada, cujo começo é escolhido pelo narrador. Essa 'pré-história' da história é o que liga esta a um todo mais vasto e lhe dá um 'pano de fundo"' (RICOEUR, 2010a, p. 129). No caso dos "documentários de memória afetiva", o trauma é este pano de fundo que, como já sabemos, coloca para os cineastas um limite: o da transmissão do passado. Mas como bem lembra Ricoeur, estas experiências extremas podem ser (e são) intransmissíveis, em termos de herança, mas não indizíveis (RICOUER, 2007, p.459).

Ainda nas reflexões de Ricouer, temos que para uma narrativa não basta que esta seja aceitável, que os episódios reunidos em 
uma determinada lógica sejam coerentes com a história contada, é necessário que faça sentido ao mundo do leitor/espectador. Então, o documentário, ao recorrer aos vestígios - sejam eles monumentos, locais traumáticos ou ruínas, documentos ou materiais de arquivo (escritos, imagéticos ou sonoros) - e aos testemunhos reveste a sua narrativa de um tom realista não só pelas informações que estas imagens operam do passado, mas também pelos compromissos, interesses que movem o documentarista em torno dessas imagens.

Tom realista este que evoca à narrativa documentária uma "intencionalidade histórica", que nos termos do autor é particular de uma narrativa (a histórica) que reivindica para si "[...] uma referência que se inscreve na empeiría, na medida em que a intencionalidade histórica visa a acontecimentos que efetivamente ocorreram" (RICOUER, 2010a, p.139). Ao considerar que a narrativa documentária também implica em uma "intencionalidade histórica", temos na recordação, ou nos usos que fazem os documentaristas dos vestígios e dos testemunhos para a composição da intriga (o agenciar dos acontecimentos), uma problemática que diz mais sobre o presente do que sobre o passado. Como já dito anteriormente, o documentário sempre fala no presente, por mais que sua referência seja o tempo passado, como é o caso dos "documentários de memória”. Presente este que é "[...] simultaneamente o que vivemos e o que realiza as antecipações de um passado rememorado. Em contrapartida, essa realização se inscreve na lembrança [...]" (RICOEUR, 2010b, p. 61).

Para a narrativa documentária é imprescindível a autenticidade das filmagens, já existe um pacto de leitura estabelecido que pressupõe menos uma narrativa verdadeira e mais uma verdade do referente. Em outras palavras, o espectador do documentário espera/exige que o mundo vivido ou as experiências humanas, configuradas em uma lógica interna no filme, sejam verdadeiros.

Podemos pensar sobre a perspectiva do "pacto autobiográfico" como proposto por Philippe Lejeune. Para ele, a autobiografia se apõe a todas as formas de ficção por ser um texto referencial, assim como o discurso científico e o histórico. Primeiro, o "pacto autobiográfico" exige tanto um sujeito da enunciação quanto um enunciado na primeira pessoa; e segundo, ele expõe um pacto referencial em que este sujeito na primeira pessoa se propõe "[...] a fornecer informações a respeito de uma 'realidade' externa ao texto e a se submeter portanto a uma prova de verificação. Seu objetivo não é a simples verossimilhança, mas a semelhança com o verdadeiro. Não o 'efeito de real', mas a imagem do real" (LEJEUNE, 
2014, p. 43, grifo do autor). Segundo o autor, o imperativo da semelhança no discurso autobiográfico é um aspecto secundário, pois mesmo que se julgue que a semelhança não foi alcançada, o que importa é saber que ela foi visada, que o autor se esforçou duplamente ao representar “[...] 1) a sua relação com o passado; 2) esse passado tal qual era, com a intenção de nada modificar" (LEJEUNE, 2014, p. 48).

No caso do documentário se convencionou a pensar nele como um discurso que exige provas, pois pretende ser uma narrativa verossímil, convincente e comovente, em termos retóricos. Porém, quando olhamos mais a fundo para os documentários autobiográficos presenciamos uma mudança de foco nas estratégias narrativas do próprio documentário, em que relatos pessoais com ramificações sociais e históricas podem ser também verossímeis, convincentes e comoventes, sem que sejam definitivos ou conclusivos. Segundo Bill Nichols (2005, p. 82),

Muitas vezes, essa união serve para estabelecer credibilidade e conviç̧ão, já que o cineasta começa com o que conhece melhor - a experiência familiar - e, dela, estende-se para o mundo exterior. [...]. A própria subjetividade compele à credibilidade: em vez de uma aura de veracidade absoluta, temos a aceitação sincera de uma visão parcial, mas muito significativa; situada, mas apaixonada.
Em 1987, Lejeune escreveu Cinéma et autobiografhie: problémes de vocabulaire, para a Revue Belge du Cinéma, número 14, em que apresentou uma grande dificuldade em pensar um cinema autobiográfico, mas reconheceu ao final que, devido a alguns aspectos evolutivos deste cinema, em termos de linguagem - como a utilização da voz offe a invenção da câmera subjetiva, assim como do aparecimento de equipamentos mais leves, como o super-8, atrelado ao desenvolvimento da televisão e do vídeo - "o cinema autobiográfico começa portanto a existir, diferente da autobiografia escrita, mas também diferente do cinema de ficção, sendo um meio caminho entre o cinema amador e o cinema experimental" (LEJEUNE, 2014, p. 271), e que sob esta perspectiva trata-se de "[...] uma aventura que se deve acompanhar com curiosidade" (p. 274).

Já para Timothy Corrigan (2015), a proliferação dos filmes autobiográficos somente nas décadas de 1960 e 1970 foi um sinal atrasado das mudanças que já se processavam desde 1940, após os traumas culturais e históricos originários da Segunda Guerra Mundial. No pós-guerra, o lugar e o valor da subjetividade e da identidade foram cada vez mais questionados, principalmente porque os acontecimentos daquele conflito bélico haviam abalado definitivamente a crença na autoridade do sujeito humanista. Mesmo que tardia, a resposta dada pelo cinema veio pela via do 
filme-ensaio, assim como acreditava Lejeune (2014), e reiterado por Corrigan (2015) para quem este cinema está "A meio caminho da ficção e da não ficção, das reportagens jornalísticas e da autobiografia confessional, dos documentários e do cinema experimental". Segundo o autor, em um filme-ensaio o realizador "[...] executa uma apresentação performativa do eu como uma espécie de autonegação em que estruturas narrativas ou experimentais são subsumidas no processo do pensamento por meio de uma experiência pública" (p.10). Relacionando com o "documentário de memória afetiva" o que está em jogo não é a maneira como o filme privilegia a expressão e a subjetividade pessoais do documentarista, mas, acima de tudo, “[...] a maneira como perturba e complica essa própria noção de expressividade e sua relação com a experiência" (p. 21, grifo do autor), uma vez que a expressão ensaística “[...] exige a perda do eu e o repensar e refazer o eu" (p.21).

Considerando que o ponto central desta expressão ensaística é o tom pessoal ou subjetivo que ajuda o realizador a organizar suas observações e reflexões, não podemos esquecer a herança literária do filme-ensaio que inclui, entre outras práticas, os escritos biográficos e autobiográficos, e que neste tipo de cinema encontram ressonância duas versões do filme-ensaio: o retratístico e o autorretratístico (p.81). O filme-ensaio autorretratístico vem satisfazer, em termos conceituais, o que venho apresentando aqui como "documentário de memória afetiva", tendo em vista que estamos falando de um cinema que, ao estabelecer um "pacto autobiográfico" com os espectadores, o faz por se apresentar “[...] como uma investigação da essência da própria subjetividade como multiplicação e perda. Ela se torna uma intensificação do pensar o eu como discurso público, experiência e história - e nessa intensidade surge o vínculo essencial entre autoexpressão e morte" (CORRIGAN, 2015, p. 97).

\section{Testemunha de si}

O cinema documentário foi sensível à "guinada subjetiva" dos anos de 1970/80 em que se reconheceram os direitos e a verdade da subjetividade nas narrativas da memória, tanto na literatura quanto na história. Vimos a aparição de novos sujeitos (os marginalizados, os excluídos), reconheceu-se o lugar da subjetividade no narrado (a primeira pessoa da narração). Enquanto que o testemunho, eleito como ícone de verdade ou recurso mais importante para a compreensão do passado (SARLO, 2007), deu ao relato em primeira pessoa maior credibilidade ao ser interpretado como tradução da experiência do vivido.

No bojo desta guinada subjetiva, presenciamos o surgimento de um tipo de documentário que colocou o cineasta em primeiro plano, 
deslocou o olhar da alteridade do Outro para um Eu intimista e singular. Para Nichols (2005), as melhores obras do que ele denominou de documentário performático são aquelas que conseguem conjugar o relato da vida pessoal do cineasta com alguns aspectos sociais e históricos de um mundo que lhe é exterior. Ainda segundo o autor,

Esses filmes nos envolvem menos com ordem ou imperativos retóricos do que com uma sensação relacionada com sua nítida sensibilidade. A sensibilidade do cineasta busca estimular a nossa. Envolvemo-nos em sua representação do mundo histórico, mas fazemos isso de maneira indireta, por intermédio da carga afetiva aplicada ao filme e que o cineasta procura tornar nossa (2005, p.171).

Mas para melhor compreendermos este tipo de cinema documentário temos que a noção de performance deve ser entendida como "[...] um processo de leitura, interpretação e devolução que integram o mecanismo maior $d a$ consciência histórica do sujeito - daquele que filma, mas também de quem é filmado e de quem assiste" (MOLFETTA, 2006, p.202). Entendimento que coaduna com o de Taylor (2013), como demonstrarei mais adiante, e que para as reflexões aqui lançadas servem como um norte teórico. Nestes termos, no documentário performático o que está em evidência são as dimensões subjetivas e afetivas com as quais o diretor se relaciona com o mundo, e é comum que ocorra nestes filmes uma combinação entre o real e o imaginado. O cineasta nos apresenta o mundo de maneira emocional, dá mais ênfase nas características subjetivas da experiência e da memória, que, por sua vez, se afasta do relato objetivo (NICHOLs, 2005, p.170). Cabe ao analista um olhar detalhado de como filmicamente estas características subjetivas da experiência e da memória são postas em cena por meio de uma ação performática do documentarista.

A despeito da importância desta modalidade de documentário para a contemporaneidade, ressalvas precisam ser feitas. Primeiro, o cinema documentário é (e sempre foi) subjetivo. Se por um lado o caráter indexado das imagens e dos sons do mundo é um forte componente do aspecto objetivo do documentário, não se pode esquecer que direcionar a câmera para um determinado lugar, posição, objeto ou personagem já pressupõe um gesto subjetivo do realizador. Um gesto que "está" no mundo e procura interpretá-lo. A maquinaria da câmera pode sugerir um caráter objetivo no ato de registrar o real, mas é o olhar humano, a percepção, que conduz o disparo da tomada. Não obstante, dizer que o documentário é assumidamente subjetivo não implica em negar a objetividade que também lhe compete.

A segunda ressalva diz respeito ao fato de que nem sempre o documentário em primeira 
pessoa escapa a uma narrativa expositiva, o que se nota em alguns filmes é que o relato em primeira pessoa é um mero recurso narrativo. Ao estudar algumas variantes de narrativas documentárias em primeira pessoa, Pablo Piedras (2014, p. 83, tradução nossa) nos chama a atenção para o fato de que,

[...] certas vozes em primeira pessoa se convertem em um recurso que não se limita a expressar uma subjetividade ou a distribuir informações necessárias para a organização e compreensão do relato, mas se arrogam uma forte dose de autoridade textual sobre os outros níveis de discurso audiovisual $[\ldots]^{3}$

Desse modo, isso faz com que elas sejam semelhantes a voz off ( a "voz de Deus") dos documentários tradicionais. Por fim, é preciso que se diga que a reflexividade e a performatividade nos modos discursivos e de representação no documentário não colocaram em crise o modo expositivo. $O$ expositivo é ainda o modelo predominante de documentário na maioria das filmografias dos cinemas mundiais, contudo, desde a década de 1960, este tipo de cinema vem contando com os métodos de entrevistas para incorporar um novo elemento a sua narrativa: o testemunho. No documentário expositivo, as falas das pessoas filmadas têm o mesmo papel do que os materiais de arquivos, imagens, documentos, ou seja, devem funcionar como provas que configuram credibilidade e convençam os espectadores do argumento do filme. Estão mais a serviço de um discurso fílmico do que de representar uma situação de alteridade que pressupõe todo encontro do documentarista com a pessoa filmada.

Em seu estudo Piedras (2014) identificou três modalidades da narrativa em primeira pessoa no documentário. São elas:

1. o relato de experiência e alteridade - um sujeito fala com o outro; aqui o relato em primeira pessoa demarca uma relação em que sujeito e objeto são ambos afetados. Ninguém sai impune do encontro proporcionado pela situação de filmagem, o olhar subjetivo do realizador permite colocá-lo, assim como o objeto do relato, em uma condição de transformação em termos de experiência e percepção do mundo;

2. o relato epidérmico - um sujeito que fala sobre o outro; o sujeito que narra não possui vínculo com a história que 
conta, é "una presencia desencarnada". Neste caso, estamos distantes de uma narração da experiência que revela ou que coloca um "eu" em uma situação de conflito consigo mesmo ou com o mundo vivido. Na maioria das vezes, a narrativa em primeira pessoa neste tipo de relato satisfaz mais um gesto retórico (e/ou egocêntrico) do realizador que se beneficia de artifícios narrativos, como o corpo em cena e a exacerbação da subjetividade, para plasmar uma narrativa que sugere uma versão pessoal e subjetiva dos fatos (PIEDRAS, 2014, p.81);

(3) a narração autobiográfica - um sujeito que fala sobre si mesmo; caracteriza-se por uma relação mais visceral entre o sujeito e objeto do enunciado, em que a narração em primeira pessoa evoca uma identidade em crise, em descoberta ou construção.

O testemunho enquanto narrativa é uma redescoberta do sujeito em si no mundo. Nos documentários autobiográficos, ou no que denominei de "documentário de memória afetiva", este testemunho é da ordem da performance, de uma performance afetiva do documentarista. O teor testemunhal destes documentários se reveste de um potencial afeccional, em que o cineasta que narra é também afetado pela narração do trauma/passado.

\section{Performance afetiva e memória traumática}

Ao analisar o trabalho de memória de uma história criminosa, como a repressão ocorrida na Argentina nos anos de 1970, a partir das manifestações públicas dos H.I.J.O.S que promovem escraches nas ruas, denunciando os sequestradores, torturadores e assassinos de seus familiares, Taylor comenta como o político da performance auxilia na transmissão da memória traumática. "Se a performance transmite a memória traumática e o comprometimento político, parece que nós, que os acompanhamos, recolhemos essa memória" (TAYLOR, 2013, p. 232). Nestes termos, ao atentarmos para a relação entre performance e memória traumática, e suas implicações para a narrativa de documentários autobiográficos, reconhecemos o potencial político deste tipo de cinema que vem marcado, na sua origem, de um dever moral do cineasta com o passado que é retratado. Não se trata de um interesse ou curiosidade que nasce do estudo, da pesquisa de um determinado fato histórico, da vontade de conhecer ou descobrir algo que nos remeta a um acontecimento passado, como ocorre com os cineastas na maioria dos documentários ditos históricos; a vontade é mais forte que o realizador, o filme nasce de uma obrigação de dizer algo, de narrar e recordar para não esquecer; nestes filmes também há descobertas, mas em geral são da ordem do afetivo. 
Ao procurar respostas para a questão de como a performance transmite a memória traumática, Taylor (2013, p.235) aponta que "o protesto em forma de performance auxilia os sobreviventes a lidar com o trauma individual e coletivo, usando-o para incentivar a denúncia política", o mesmo acredito pode ser aplicado ao "documentário de memória afetiva”. O filme, na perspectiva de um dever de memória, coloca o cineasta neste mesmo lugar de rememoração. Ela acrescenta que "o trauma, como a performance, caracteriza-se pela natureza de suas repetições" e que "ambos se fazem sentir afetiva e visceralmente no presente", por isto pensarmos a performance do documentarista nestes filmes como uma performance afetiva da memória. Para a autora, no que se refere ao trauma e a performance "cada um intervém no corpo individual/político/social em um momento particular e reflete tensões específicas". E, por fim, "a memória traumática frequentemente conta com a performance interativa e ao vivo para sua transmissão", em que "dar testemunho é um processo ao vivo, um fazer, um evento que acontece em tempo real, na presença de um ouvinte que 'passa a ser participante e coproprietário do acontecimento traumático"' (p. 235).

No "documentário de memória afetiva" não só os espectadores, mas todos aqueles com quem o cineasta se relaciona (os personagens sociais) durante a feitura das filmagens se transformam neste "participante e coproprietário do acontecimento traumático"' (p.235). Na visão de Taylor (2013), o ato de testemunhar é transferível. Nestes termos, em um filme em que o narrador é também uma testemunha, considerando que a narrativa autobiográfica apresenta uma dependência do teor testemunhal, a interação entre personagens sociais, narrador/cineasta e os espectadores ocorre pela via do afeto, ou do potencial afeccional do encontro entre estes sujeitos e os corpos filmados, uma vez que "[...] o humor, a intensidade, a beleza dessas performances [em primeira pessoa] frequentemente se originam do ato de captar o pequeno, o pessoal, o confessional, fazendo-os falar para uma comunidade organizada ao redor de uma 'identidade', sem limitar-se a ela" (p. 318).

No caso dos "documentários de memória afetiva", os cineastas visam a transmissão ou “contágio" da memória traumática no espectador até para cumprir o seu fim político, o de não esquecer, mas sabe que ao chegar ao final do filme a dor permanece sua, pois como nos adverte Taylor (2013, p. 236) existem diferenças entre performance e trauma:

Na performance, os comportamentos e as ações, podem ser separados dos atores sociais que os performatizam. Essas ações podem ser aprendidas, encenadas e passadas para outras pessoas. A transmissão da experiência traumática se parece 
mais com o 'contágio' - uma pessoa 'pega' e incorpora o peso, a dor e a responsabilidade de comportamentos/acontecimentos passados. A experiência traumática pode ser transmissível, mas é inseparável do sujeito que a sofre.

Taylor (2013) reconhece, apoiada em Victor Turner, que as performances não são capazes de "nos dar acesso a outra cultura, permitindo vê-la em profundidade, mas elas certamente nos dizem muito sobre nosso desejo desse acesso e refletem a política de nossas interpretações" (p. 32). Por isso reconhecemos que as performances dos cineastas nos "documentários de memória afetiva", apesar de não ser uma ponte direta à memória involuntária, podem nos dizer muito sobre o desejo destes documentaristas em atravessar esta ponte, além do filme refletir uma vontade política de memória. As interpretações de suas memórias traumáticas é um gesto político com os outros que também fazem parte de sua história.

O transmissível aqui da memória traumática é da ordem da herança. "É a justiça que, ao extrair das lembranças traumatizantes seu valor exemplar, transforma a memória em projeto; e é esse mesmo projeto de justiça que dá ao dever de memória a forma do futuro e do imperativo" (RICOUER, 2007, p.101). Entretanto, segundo o autor, esta relação entre justiça e dever de memória precisa ser problematizada sob três aspectos: (1) o dever de memória é fazer justiça para outra pessoa que não aquela que recorda; a justiça é voltada, por excelência, para o Outro e não para si; (2) é preciso não confinar este sentimento de dever de memória a uma noção de culpabilidade, o que está em jogo é uma "escrita com dívida", o sujeito que rememora é uma pessoa em dívida com o seu passado, com um sentimento de dever a outros, por isto narrar; narrativa que aqui é compreendida sob a forma de transmissão cultural, em que "A ideia de dívida é inseparável da de herança”; e (3) por fim, é preciso considerar que "[...] dentre esses outros com quem estamos endividados, uma prioridade moral cabe às vítimas", que na visão do autor "[...] a vítima em questão aqui é a vítima outra, outra que não nós" (p. 101-102).

Mesmo reconhecendo que "os materiais do arquivo dão forma à prática incorporada de inumeráveis maneiras, mas nunca ditam totalmente a incorporação" (TAYLOR, 2013, p.51), ou seja, que o filme, enquanto "mídia de memória", só nos oferece à análise fragmentos de um repertório, de uma memória cultural em transformação, desprezar a performance como uma forma de reter a memória cultural não nos parece ser plausível estando diante destes "documentários de memória afetiva”. É preciso lembrar que há situações em que não há documentos, fotografias, vestígios, logo, só resta aos sobreviventes acionar o repertório. É o que vemos no documentário A imagem que 
falta (2013), em que Rithy Panh recorre a bonecos de argila para reconstruir a comunidade em que ele morava com a família em Phnom Penh, capital do Camboja nos anos de 1970. Rithy Panh é sobrevivente da revolução do Khmer Vermelho, responsável pelo massacre de mais de um milhão de pessoas no Camboja, no período de 1975 a 1979, e sua obra cinematográfica é dedicada a rememorar este trágico capítulo da história recente de seu país.

Segundo Leandro (2014, p. 5), "Na obra de Rithy Panh, a escrita da história na primeira pessoa não remete a uma subjetividade ou a uma voz que diz 'eu', mas ao testemunho do outro - as vítimas, os mortos e seus algozes, que testemunham diante do cineasta”. Entretanto, como alerta a autora, o filme A imagem que falta é a primeira investida do diretor na narrativa documentária em primeira pessoa, aqui a história cambojana se confunde com a da família de Rithy Panh. "Eu busco a minha infância como uma imagem perdida" declara o documentarista logo na primeira sequência do filme, no entanto, ao final conclui para nós espectadores que ele não encontrou a imagem que faltava de sua infância, e que, portanto, ele a criou para nós, "[...] para que não parem de olhar para nós". O documentário coloca em diálogo imaginário e memória, apresenta uma narrativa em primeira pessoa que, associada a cenas reconstituídas com os bonecos, e outros dispositivos como imagens de arquivo e trilhas, constrói uma atmosfera de forte potencial de afeccção em nós espectadores. Mesmo que a performance não ocorra ao vivo, pois estamos falando de um filme, somos provocados a participar desta performatização da memória, ao ponto de sentirmos"[...] ao mesmo tempo contaminados pelo espetáculo e responsáveis por se posicionarem em relação a ele" (TAYLOR, 2013, p.118). Na ausência de imagens - aquelas que ajudariam a provar o horror que significou o massacre em Phnom Penh, e do qual se procurou apagar da história - em A imagem que falta (2013) "Somente por meio da performance pode-se tornar visível o desaparecimento" (TAYLOR, 2013, p.284).

\section{Considerações finais}

A performance aqui entendida para pensar o "documentário de memória afetiva" não se reduz à teatralidade a qual o conceito está historicamente associado, tampouco a atitude performática do documentarista deve ser interpretada como um mero estar em cena. Em A imagem que falta (2013) não vemos Rithy Panh - ou vemos sua imagem desfocada -, logo, a performance afetiva do qual se tratou neste artigo não deve ser reduzida a uma ação performativa dos corpos filmados, sobretudo do corpo do documentarista. É isto, mas não só isto. Traduz-se em uma forma de estar no mundo capaz de interpretar e transformar/atualizar o passado retratado, tendo em vista que 
"[...] as performances entram em diálogo com a história do trauma sem que elas próprias sejam traumáticas. Elas são trabalhos elaborados cuidadosamente, que criam uma distância crítica para 'reivindicar' a experiência e possibilitar a ação de testemunhar, ao invés de seu 'colapso'" (TAYLOR, 2013, p. 292).

Ter o documentário como uma valiosa "mídia de memória" (ASSMANN, 2011) da contemporaneidade implica em interpretá-lo como um documento vivo, que comunica, interpela o espectador. No caso dos "documentários de memória afetiva", estes atuam politicamente na ordem da afetação, os sujeitos que se relacionam com a narração (seja o realizador, os demais personagens sociais, e os espectadores) são todos afetados pelo trauma (ou por sua narrativa) das mais diversas ordens. Atravessado por uma performance afetiva da memória, ditado por um "pacto autobiográfico" (LEJEUNE, 2014), este documentário se reveste de uma expressão ensaística marcada pela experiência do Eu (CORRIGAN, 2015), que não se abdica da relação com o Outro, mas que prioriza uma reescrita do Eu pela via do testemunho/rememoração do trauma.

O “documentário de memória afetiva” exige que o documentarista se coloque no lugar da testemunha, é na sua essência um executar e inventar o testemunho de si. Apesar de não ser um processo ao vivo, este tipo de filme não deixa de ter um potencial performático, que encontra na recordação um gesto revestido de uma potência afeccional. A forma como o filme testemunha/atualiza o passado, na chave do trauma, convida os espectadores a serem coparticipantes do acontecimento traumático (TAYLOR, 2013). Por mais que a dor do trauma é indissociável daquele que narra, neste tipo de documentário a performance afetiva da memória vem satisfazer um dever moral do realizador com os seus mortos, uma vontade política de memória em que narrar não basta, é preciso afetar o Outro. A afetação torna-se estratégia para acessar uma dimensão do evento traumático que seja narrável, compartilhado com aquele que não sofre do trauma. Mesmo sabendo que se trata de uma visão parcial, os espectadores deste tipo de documentário não se importam com isso, pois o pacto assumido os coloca diante de uma narrativa subjetiva em que sua densidade é da ordem da experiência humana.

\section{Referências}

ABBAGNANO, Nicola. Dicionário de Filosofia. São Paulo: Martins Fontes, 2007.

ASSMANN, Aleida. Espaços da recordação: formas e transformações da memória cultural, Campinas, SP: Editora da Unicamp, 2011.

BENJAMIN, Walter. Obras escolhidas III: Charles Baudelaire; um lírico no auge do capitalismo. Tradução e organização Paulo Sérgio Rouanet. São Paulo: Brasiliense, 1989. (v.3). 
COMOLLI, Jean-Louis. Ver e poder: a inocência perdida; cinema, televisão, ficção, documentário. Belo Horizonte: UFMG, 2008.

CORRIGAN, Timothy. O filme ensaio: desde Montaigne e depois de Marker. Campinas, SP: Papirus, 2015.

GAUTHIER, Guy. O documentário: um outro cinema, Campinas, SP: Papirus, 2011.

HARTOG, François. Regimes de historicidade: presentismo e experiências do tempo. Belo Horizonte, MG: Autêntica, 2014.

HUYSSEN, Andreas. Seduzidos pela memória: arquitetura, monumentos, mídia. Rio de Janeiro: Aeroplano, 2000.

IZQUIERDO, Iván. A arte de esquecer: cérebro e memória. Rio de Janeiro: Vieira \& Lent, 2010.

LEANDRO, Anita. A história na primeira pessoa: em torno do método de Rithy Panh. E-compós, Brasília, v.19, n.3, p.1-15, set./dez. 2016. Disponível em <http://www.compos. org.br/seer/index.php/e-compos/article/ viewFile/1279/903>. Acesso em: 22 fev. 2018.

\section{LEJEUNE, Philippe. 0 pacto autobiográfico:} de Rousseau à internet. Belo Horizonte, MG: Editora UFMG, 2014.

MOLFETTA, Andrea. Documentário performático e filosofia hermenêutica no Cone Sul. In: MONZANI, Josette; BERNADETTE, Lyra (Org.). Olhar: cinema. São Paulo: Ed. Pedro e João Editores; CECH - UFSCAR, 2006. p.196-205.

NICHOLS, Bill. Introdução do documentário. Campinas, SP: Papirus, 2005.

PIEDRAS, Pablo. El cine documental en primera persona. Ciudad Autónoma de Buenos Aires: Paidós, 2014.
RICOEUR, Paul. Tempo e narrativa: a intriga e a narrativa histórica. São Paulo: Editora WMF Martins Fontes, 2010a. (v. 1).

Tempo e narrativa: o tempo narrado. São Paulo: Editora WMF Martins Fontes, 2010b. (v. 3).

A memória, a história, o esquecimento. Campinas, SP: Editora Unicamp, 2007.

SARLO, Beatriz. Tempo passado: cultura da memória e guinada subjetiva. São Paulo: Cia das Letras; Belo Horizonte: Editora da UFMG, 2007.

SARMENTO-PANTOJA, Carlos Augusto

Nascimento. Performance, trauma e testemunho no Cinema pós-64. 2016. $225 \mathrm{f}$. Tese (Doutorado) - Instituto de Estudos da Linguagem, Universidade Estadual de Campinas, Campinas, 2016.

TAYLOR, Diana. $\mathbf{O}$ arquivo e o repertório: performance e memória cultural nas Américas. Belo Horizonte: Editora UFMG, 2013.

TOMAIM, Cássio dos Santos. O documentário como "mídia de memória": afeto, símbolo e trauma como estabilizadores da recordação.

Revista Significação, São Paulo, v. 43, n. 45, p.96-114, 2016.

WINTER, Jay. A geração da memória: reflexões sobre o "boom da memória" nos estudos contemporâneos de história. In: SELLIGMANSILVA, Márcio (Org.). Palavra e imagem: memória e escritura. Chapecó, SC: Argos, 2006. p. 67-90. 


\section{Performance and documentary of affective memory}

\section{Abstract}

It proposes an initial approximation of the relationship between performance and traumatic memory and its implications for documentary narrative in first person (autobiographical). Understands performance as an expressive behavior capable of transmitting memory and cultural identity, valuing both the repertoire and the archive, as proposed by Diana Taylor (2013). In this type of cinema the testimony is of the order of the performance, of an affective performance of the documentarist. The testimony in these documentaries is of a power of affectedness, in which the filmmaker who narrates is also affected by the narration of the trauma/past.

\section{Keywords}

Autobiographical documentary. Performance. Traumatic memory.

\section{Performance y documentario de memoria afectiva}

\section{Resumen}

Se propone una aproximación inicial de la relación entre performance y memoria traumática y sus implicaciones para la narrativa de lo cine documental en primera persona (autobiográfica).Entiende performance como un comportamiento expresivo capaz de transmitir la memoria y la identidad cultural, a partir de la valorización tanto del repertorio y del archivo, como propuesto por Diana Taylor (2013).En este tipo de cine el testimonio es del orden de la performance, de una performance afectiva del documentalista. El contenido testimonial de estos documentales ten un potencial afeccional, en el que el cineasta que narra también es afectado por la narración del trauma/pasado.

\section{Palabras clave}

Cine documental autobiográfico.

Performance. Memoria traumática.

\section{Cássio dos Santos Tomaim}

Doutor em História pelo Programa de Pós-Graduação em História da Universidade Estadual Paulista "Júlio de Mesquita Filho" (Unesp), campus Franca (SP). Professor do Departamento de Ciências da Comunicação e do Programa de Pós-Graduação em Comunicação da Universidade Federal de Santa Maria - UFSM, Santa Maria, Rio Grande do Sul, Brasil. | E-mail: tomaim78@gmail.com ORCID: https://orcid.org/0000-0003-0822-831X 